Patrícia Aparecida Barbosa Silva'

Sônia Maria Soares"

Joseph Fabiano Guimarães
Santos

Santos

Líliam Barbosa Silva'

\section{Cut-off point for WHOQOL- bref as a measure of quality of life of older adults}

\section{Ponto de corte para o WHOQOL- bref como preditor de qualidade de vida de idosos}

\begin{abstract}
OBJECTIVE: To propose a cut-off for the World Health Organization Quality of Life-Bref (WHOQOL-bref) as a predictor of quality of life in older adults.

METHODS: Cross-sectional study with 391 older adults registered in the Northwest Health District in Belo Horizonte, MG, Southeastern Brazil, between October 8, 2010 and May 23, 2011. The older adults' quality of life was measured using the WHOQOL-bref. The analysis was rationalized by outlining two extreme and simultaneous groups according to perceived quality of life and satisfaction with health (quality of life good/satisfactory - good or very good self-reported quality of life and being satisfied or very satisfied with health-G5; and poor/very poor quality of life - poor or very poor self-reported quality of life and feeling dissatisfied or very dissatisfied with health - G6). A Receiver-Operating Characteristic curve (ROC) was created to assess the diagnostic ability of different cut-off points of the WHOQOL-bref.
\end{abstract}

RESULTS: ROC curve analysis indicated a critical value 60 as the optimal cut-off point for assessing perceived quality of life and satisfaction with health. The area under the curve was 0.758 , with a sensitivity of $76.8 \%$ and specificity of $63.8 \%$ for a cut-off of $\geq 60$ for overall quality of life (G5) and sensitivity $95.0 \%$ and specificity of $54.4 \%$ for a cut-off of $<60$ for overall quality of life (G6).

CONCLUSIONS: Diagnostic interpretation of the ROC curve revealed that cut-off $<60$ for overall quality of life obtained excellent sensitivity and negative predictive value for tracking older adults with probable worse quality of life and dissatisfied with health.

DESCRIPTORS: Aged. Quality of Life. Self-Assessment. Questionnaires, utilization. ROC Curve. Cross-Sectional Studies.

\author{
Correspondence: \\ Patrícia Aparecida Barbosa Silva \\ Av. Augusto de Lima, 1674 Apto 1204 Barro \\ Preto \\ 30190-001 Belo Horizonte, MG, Brasil \\ E-mail: ligemeasbh@yahoo.com.br \\ Received: 4/24/2013 \\ Approved: 2/26/2014
}

Article available from: www.scielo.br/rsp e Enfermagem. Universidade Federal de

Departamento de Enfermagem Básica.

Hospital Governador Israel Pinheiro. Belo Horizonte, MG, Brasil 


\section{RESUMO}

OBJETIVO: Estimar o ponto de corte para o World Health Organization Quality of Life-Bref (WHOQOL-bref) como preditor da qualidade de vida de idosos.

MÉTODOS: Estudo transversal com 391 idosos registrados no Distrito Sanitário Noroeste, Belo Horizonte, MG, de 8 de outubro de 2010 a 23 de maio de 2011. O instrumento WHOQOL-bref foi utilizado para avaliação da qualidade de vida dos idosos. A análise foi racionalizada por meio da definição de dois grupos extremos e simultâneos em relação à percepção da qualidade de vida e satisfação com a saúde (qualidade de vida boa/satisfeito - autorrelato de qualidade de vida boa ou muito boa e se sentem satisfeitos ou muito satisfeitos com sua saúde - G5; e qualidade de vida ruim/insatisfeito - autorrelato de qualidade de vida ruim ou muito ruim e se sentem insatisfeitos ou muito insatisfeitos com sua saúde - G6). A curva Receiver-Operating Characteristic (ROC) foi construída para avaliar a capacidade diagnóstica de diferentes pontos de corte do instrumento WHOQOL-bref.

RESULTADOS: A análise da curva ROC indicou valor crítico 60 como o melhor ponto de corte para avaliação da percepção de qualidade de vida e satisfação com a saúde. A área sob a curva foi 0,758 , com sensibilidade de $76,8 \%$ e especificidade de $63,8 \%$ para o ponto de corte de qualidade de vida geral $\geq 60$ (G5); e sensibilidade de $95,0 \%$ e especificidade de $54,4 \%$ para o ponto de corte de qualidade de vida geral $<60$ (G6).

CONCLUSÕES: O ponto de corte qualidade de vida geral $<60$ obteve excelente sensibilidade e valor preditivo negativo para rastreamento de idosos com provável pior qualidade de vida e insatisfação com a saúde.

DESCRITORES: Idoso. Qualidade de Vida. Autoavaliação. Questionários, utilização. Curva ROC. Estudos Transversais.

\section{INTRODUCTION}

The rapid aging of the population poses a challenge for the governments of many countries. The number of older adults in 2012 was approximately 810 million, and is predicted to reach 1 billion within the next 10 years, doubling by 2050 . This becomes still more alarming when we consider that $80.0 \%$ of the long-lived will be living in less developed places. ${ }^{a}$

In Brazil in 2012, the number of older adults exceeded 24 million individuals, more than $12.0 \%$ of the Brazilian population. ${ }^{\mathrm{b}}$

The growth of the older population in Brazil is no longer a distant possibility, it is occurring now, due to rapid demographic transition accompanied by epidemiological changes. Complex changes in the health-disease model have been observed, with a predominance of communicable diseases shifting to higher prevalence of chronic non-communicable disease. ${ }^{\mathrm{c}}$

The greatest challenge of the $21^{\text {st }}$ century will be to care for the large number of older adults with poor levels of socioeconomic status and education and a high prevalence of chronic comorbidities. Such comorbidities are responsible for physiological limitations, functional decline, loss of autonomy, increased dependence, social isolation, suffering and depression. ${ }^{18}$

Increased spontaneous demand, by older adults, for health care prevention and maintenance programs requires greater investment in research into aging. In this population, the majority of situations of dependence are associated with chronic conditions. However, these conditions can be managed appropriately outside of hospitals or residences, above all in primary care.

\footnotetext{
a United Nations Population Fund. Aging in $21^{\text {st }}$ century: Celebration and Challenge: executive summary. New York.

b Instituto Brasileiro de Geografia e Estatística. Pesquisa Nacional por Amostra de Domicílios. Rio de Janeiro: IBGE; 2012.

c Mendes EV. O cuidado das condições crônicas na Atenção Primária à Saúde: o imperativo da consolidação da Estratégia da Saúde da

Família. Brasília (DF): Organização Pan-Americana da Saúde; 2012.
} 
Over the last few decades, concern about the quality of life in this population has increased. This is a complex concept with diverse meanings, a variety of theoretical approaches and for which countless ways of measuring exist. ${ }^{10}$

Quality of life, according to the World Health Organization Quality of Life Group (WHOQOL Group), is defined as the individual's perception of their position in life in the context of the culture and the value system they inhabit, in relation to expectancies, patterns and concerns. ${ }^{19}$ This concept is based on the definition of health itself, as proposed by the World Health Organization, interpreted as the individual's perception of their overall wellbeing, both mental and social, rather than simple absence of disease. ${ }^{d}$

Quality of life has been dealt with in the most varied of ways, both in the choice of instrument used to evaluate it and in the diversified target population. ${ }^{2,9,11}$

Brazilian research assessing quality of life status in the long-lived is incipient and conducted using different instruments, which makes it difficult to compare the data. ${ }^{1,3,7}$

The instruments drawn up by the WHOQOL group - the WHOQOL-100, the WHOQOL-bref and the WHOQOL-old - contain three essential aspects: subjectivity, multi-dimensionality and the presence of positive and negative dimensions in their particular characteristics..$^{5,6}$

These instruments provide an overall score and a score by domain for quality of life. However, there is no cut-off point to demonstrate better or worse quality of life. It would be useful if there were a cut-off point to better define perceived quality of life and satisfaction with health in older adults.

New methodology to evaluate the scores produced by the above mentioned instruments has made significant contributions to scientific progress in this area. This is the first study to describe such a method. It may be useful for health care administrators and managers, who could use it to aid in drawing up public policy to promote healthy ageing.

The aim of this study was to estimate a cut-off point for the WHOQOL-bref instrument as a predictor of quality of life in older adults.

\section{METHODS}

This was a cross-sectional study with 391 older adults registered in primary health care units in the Northwest Health District in Belo Horizonte, MG, Southeastern Brazil, between October 8, 2010 and May 23, 2011.
This district was chosen as it has the largest absolute number of residents aged $\geq 60$ registered in primary health care units in the areas.

The subjects were those who considered themselves in need of, and sought, health care services. The sample depended on spontaneous demand and on scheduled appointments during the data collection period.

The sample size was calculated based on the Lwanga \& Lemeshow formula, ${ }^{12}$ requiring the following data: a) proportion in the population: $\mathrm{P}$; b) level of significance: $100(1-1 \mathrm{X}) \%$; c) absolute precision (in percentage points): $\mathrm{d}$.

The sample calculation was based on the prevalence of primary health care service use by older adults, provided by the Brazilian Unified Health System (SUS) Outpatient Information System (32.0\%), ${ }^{\mathrm{e}}$ with a $5 \%$ level of significance and absolute precision of five percentage points. The sample size was 334 older adults. The final sample total was 401 older adults, considering $20.0 \%$ possible losses, and represented $0.9 \%$ of the elderly population of the health district.

The 401 older adults were distributed proportionally between the district's 20 primary health care units, based on the formula: $\mathrm{n}=\mathrm{N}$ x Ni/total ( $\mathrm{n}$ : calculated sample; N: number of older adults registered in each primary health care unit; $\mathrm{Ni}$ : number of older adults in the sample - 401; Total: total number of older adults of the population in question -44,801).

Criteria for inclusion were: being of either sex; aged $\geq 60$; having used primary health care services in the district; having consented to take part; and having completed the questionnaire.

Older adults with severe cognitive impairment (MiniMental State - MMSE scores $\leq 9$ ), which made it impossible to complete the questionnaire, were excluded. ${ }^{14}$

Of the 401 questionnaires, 399 were located and reviewed, one by one. Two were excluded as only the identification page had been completed, another as more than $20.0 \%$ of the questions in the WHOQOL-bref had not been completed, and a further five because the individuals were aged $<60$, giving a total of 391 valid questionnaires ( $97.5 \%$ of the calculated sample). None of the older adults were excluded for having severe cognitive impairment (MMSE: 23.2; $\mathrm{SD}=5.1$ ).

Data were collected by a previously trained team of two nurses and three Iniciação Cientifica scholarship holders. Participants were approached in primary health care units while waiting to be seen by a doctor and/ or waiting for other services, during the morning and afternoon shifts, according to interviewer availability.

${ }^{d}$ World Health Organization. The first ten years of the World Health Organization. Geneva; 1958.

e Ministério da Saúde, Departamento de Informática do SUS/DATASUS. Produção ambulatorial. Brasília (DF); 2012 [cited 2012 Oct 20 ]. Available from:

http://w3.datasus.gov.br/siasih/siasih.php 
A pre-test was conducted with 13 older adults registered in one of the primary care units studied, which was the workplace of one of the team members. No difficulty was observed in their understanding of the questionnaire.

The short version, in Portuguese, of the WHOQOL-bref was used. The instrument, which has a good response to the quality of life in older adults, ${ }^{13,15,16}$ performs well psychometrically, is easy to use and has been translated and validated for use in Brazil, providing one option for evaluating quality of life in this country. ${ }^{6}$

The WHOQOL-bref contains 26 items; the first two questions evaluate self-perceived quality of life (denominated WHOQOL-1) and satisfaction with health (denominated WHOQOL-2). The remaining 24 questions represent each of the 24 facets of which the original instrument is composed (WHOQOL-100), divided into four domains: physical, psychological, social relationships and environment. In contrast to the WHOQOL-100, in which each of the 24 facets is evaluated using four questions, in the WHOQOL-bref only one question is used: that which has the highest correlation with the total score, calculated by the mean of all the facets ${ }^{4}$

The WHOQOL-bref contains five Likert style response scales: "very poor to very good" (evaluation scale), "very dissatisfied to very satisfied" (evaluation scale), "none to extremely" (intensity scale), "none to complete" (capacity scale) and "never to always" (frequency scale). ${ }^{4}$ Each domain is made up of questions for which the scores vary between one and five.

The mean score in each domain indicates the individual's perception of their satisfaction with each aspect of their life, relating it with quality of life. The higher the score, the better this is perceived to be.

Although this instrument is completed by the subject, it was decided to use direct interviews, given that difficulty reading, problems with vision and low levels of schooling are common in older adults.

There are no cut-off points above or below which quality of life could be evaluated as "poor" or "good". Thus, it was decided to rationalize the analysis by defining two groups at the extremes, both in perception of QoL and satisfaction with health (good QoL /satisfied - includes those who reported having good or very good QoL and were satisfied or very satisfied with their health; and poor QoL/dissatisfied - includes those who reported poor or very poor QoL and who were dissatisfied or very dissatisfied with their health).
Four groups were established: G1 - Good or very good perceived quality of life $=220$ individuals; G2 - poor or very poor perceived quality of life $=31$ individuals; G3 - satisfied or very satisfied with their health $=205$ individuals; G4 - dissatisfied or very dissatisfied with their health $=90$ individuals.

Based on the definition of the good QoL/satisfied and poor QoL/dissatisfied groups, the following groups were then established: G5 - Good or very good quality of life and satisfied or very satisfied with health (characteristics of G1 and G3: n = 151;38.6\%); b) G6 - Poor or very poor quality of life and dissatisfied or very dissatisfied with their health (characteristics of G2 and $\mathrm{G} 4: \mathrm{n}=20 ; 5.1 \%$ ).

A Receiver-Operating Characteristic (ROC) curve, with a $95 \%$ confidence interval was constructed to evaluate the diagnostic capacity of different cut-off points for the overall quality of life (OQoL) to predict good QoL/ satisfied or poor QoL/dissatisfied in older adults. This technique enables the discriminatory exactitude to be shown; the greater the area below the ROC curve, the greater the discriminatory power.

The diagnostic test $\mathrm{t}^{\mathrm{f}}$ was conducted for groups G5 and G6 in order to define the OQoL cut-off point for the WHOQOL-bref, it included:

a) Pre-test probability: proportion of older adults belonging to $\mathrm{G} 5$ in relation to the total sample $(\mathrm{a}+\mathrm{c} / \mathrm{a}+\mathrm{b}+\mathrm{c}+\mathrm{d})$;

b) Sensitivity or copositivity (S): proportion of older adults belonging to G5 and whom the test correctly identified by the OQoL score $\geq$ critical value $(\mathrm{a} /[\mathrm{a}+\mathrm{c}])$;

c) Specificity or conegativity (E): proportion of older adults not belonging to group G5 and whom the test correctly identified by the OQoL score $<$ critical value $(\mathrm{d} /[\mathrm{b}+\mathrm{d}])$;

d) Positive predictive value or positive post-test probability (PPV): probability of belonging to G5 and obtaining an OQoL score $\geq$ critical value, when the test is positive, i.e., the relationship between the number of older adults belonging to group G5 and with an OQoL score $\geq$ critical value, divided by the total positive results of the test studied $(a /[a+b])$;

e) Negative predictive value or negative post-test probability (NPV): probability of not belonging to group G5 and having an OQoL score $<$ critical value, when the test is negative, i.e., the relationship between the number of older adults not belonging to group G5 and with an OQoL score $<$ critical value, divided by the total negative results of the test studied $(\mathrm{d} /[\mathrm{c}+\mathrm{d}])$;

${ }^{\dagger}$ Loureiro MHVS. Validação do "Mini-Nutricional Assessment" em idosos [master's dissertation]. Coimbra: Faculdade de Medicina da Universidade de Coimbra; 2008. 
f) Positive likelihood ratio (PLR): probability of the test result being positive in older adults belonging to the G5 group and with an OQoL score $\geq$ critical value, in relation to the probability of the test result being positive in older adults not belonging to the G5 group and scoring $\geq$ critical value in the OQoL $(\mathrm{S} /[1-\mathrm{E}])$;

g) Negative likelihood ratio (NLR): probability of the test result being negative in older adults belonging to the G5 group and with a OQoL score $\geq$ critical value, in relation to the probability of the test result being negative in older adults not belonging to the G5 group and scoring $\geq$ critical value in the OQoL $([1-\mathrm{S}] / \mathrm{E})$.

The above stages were followed for the diagnostic test for the G6 group (QoL poor/very poor), considering the OQoL cut-off point $<$ critical value.

The Statistical Package for the Social Sciences (SPSS) version 20.0 program was used to analyze the data.

This study was approved by the Research Ethics Committee of the Universidade Federal de Minas Gerais (Record ETIC 0043.0.410.203-10) and by the Ethics Committee of the Belo Horizonte Municipal Health Secretariat (Record 0043.0.410.203-10A), according to National Health Council Resolution 196/96.9 Subjects signed an informed consent form. To guarantee anonymity, informants were identified by number, sequenced in the order in which they were interviewed.

\section{RESULTS}

The majority of the older adults were female (62.9\%), married or in a stable relationship (45.0\%), with none or fewer than four years of schooling $(36.5 \%)$, predominantly incomplete education in former high schools $(33.2 \%)$. The median age varied from 64.4 to 75.1 years old, with the predominant age group being 60 to 64 years old. Almost all of the older adults $(92.3 \%)$ reported some kind of health problem, the most common being systemic arterial hypertension (75.4\%), diabetes mellitus $(24.0 \%)$ and osteoarticular disease (20.7\%).

Around $56.3 \%$ of the older adults perceived their quality of life to be good or very good, and $7.9 \%$ as poor or very poor; $52.4 \%$ were satisfied or very satisfied with their health, whereas $23.0 \%$ considered it to be dissatisfactory or very dissatisfactory.

Half of the older adults scored $<60.6($ Median $=606$; IQ 54.0-65.6) in the OQoL test.

Of the 220 older adults with good or very good QoL, $68.6 \%$ were satisfied or very satisfied with their health, forming group G5 (good QoL/satisfied). There were 31 older adults who perceived their quality of life to be poor or very poor, making up group G6 (poor QoL/
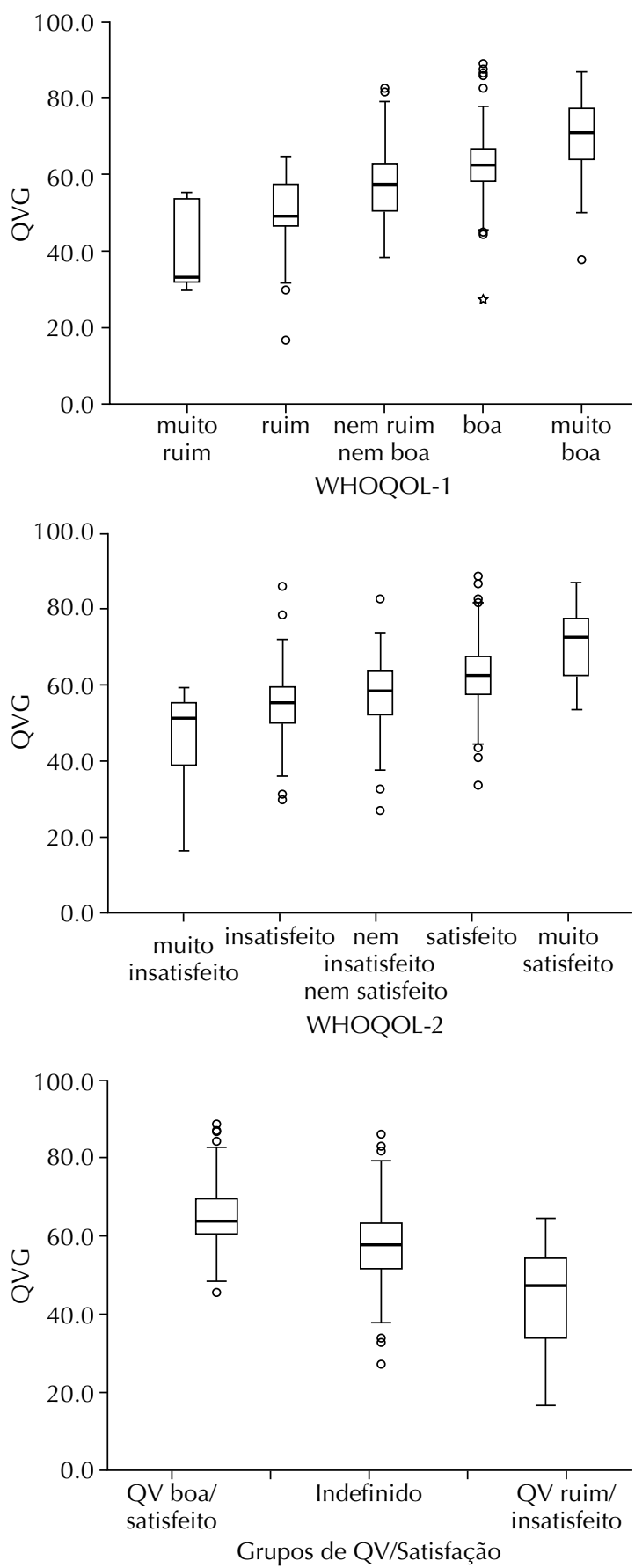

OQoL: Overall quality of life

QoL: Quality of life

WHOQOL-1: World Health Organization Quality of Life-1 WHOQOL-2: World Health Organization Quality of Life-2

Figure 1. Boxplot of the overall quality of life scores according to WHOQOL-1, WHOQOL-2 and quality of life/satisfaction groups. Northwest Health District, Belo Horizonte, MG, 2010 to 2011.

dissatisfied), of which $64.5 \%$ reported being dissatisfied or very dissatisfied with their health (Table 1).

g Ministério da Saúde, Conselho Nacional de Saúde. Resolução № 196, de 10 de outubro de 1996. Aprova as diretrizes e normas regulamentadoras de pesquisas envolvendo seres humanos. Inf Epidemiol SUS. 1996;5(2 Supl 3):13-30. 
Table 1. Frequencies for the WHOQOL-1 and WHOQOL-2 variables by groups of quality of life/satisfaction. Northwest Health District, Belo Horizonte, MG, 2010 to 2011. ( $\mathrm{N}=391)$

\begin{tabular}{|c|c|c|c|c|c|c|c|c|c|c|c|c|}
\hline \multirow{3}{*}{ Variable } & \multicolumn{10}{|c|}{ WHOQOL-2 } & & \\
\hline & \multicolumn{2}{|c|}{$\begin{array}{c}\text { Very } \\
\text { dissatisfied }\end{array}$} & \multicolumn{2}{|c|}{ Dissatisfied } & \multicolumn{2}{|c|}{$\begin{array}{l}\text { Neither satisfied } \\
\text { /Nor dissatisfied }\end{array}$} & \multicolumn{2}{|c|}{ Satisfied } & \multicolumn{2}{|c|}{ Very satisfied } & \multicolumn{2}{|c|}{ Total } \\
\hline & $\mathrm{n}$ & $\%$ & $\mathrm{n}$ & $\%$ & $\mathrm{n}$ & $\%$ & $\mathrm{n}$ & $\%$ & $\mathrm{n}$ & $\%$ & $\mathrm{n}$ & $\%$ \\
\hline \multicolumn{13}{|l|}{ WHOQOL-1 } \\
\hline Very poor & $3^{\mathrm{a}}$ & 50.0 & $1^{\mathrm{a}}$ & 16.7 & $1^{\mathrm{c}}$ & 16.7 & $1^{\mathrm{c}}$ & 16.7 & - & - & 6 & 100 \\
\hline Poor & $2^{\mathrm{a}}$ & 8.0 & $14^{\mathrm{a}}$ & 56.0 & $5^{c}$ & 20.0 & $4^{c}$ & 16.0 & - & - & 25 & 100 \\
\hline Neither poor nor good & $2^{\mathrm{c}}$ & 1.4 & $35^{\mathrm{c}}$ & 25.0 & $54^{c}$ & 38.6 & $49^{c}$ & 35.0 & - & - & 140 & 100 \\
\hline Good & $4^{c}$ & 2.1 & $26^{c}$ & 13.8 & $34^{c}$ & 18.1 & $112^{\mathrm{b}}$ & 59.6 & $12^{\mathrm{b}}$ & 6.4 & 188 & 100 \\
\hline Very good & $1^{\mathrm{c}}$ & 3.1 & $2^{\mathrm{c}}$ & 6.2 & $2^{c}$ & 6.2 & $16^{\mathrm{b}}$ & 50.0 & $11^{\mathrm{b}}$ & 34.4 & 32 & 100 \\
\hline Total & 12 & 3.1 & 78 & 19.9 & 96 & 24.6 & 182 & 46.5 & 23 & 5.9 & 391 & 100 \\
\hline
\end{tabular}

WHOQOL: World Health Organization Quality of Life

${ }^{a}$ G6: Poor quality of life/dissatisfied $(n=20)$.

${ }^{\mathrm{b}} \mathrm{G} 5$ : Good quality of life /satisfied $(\mathrm{n}=151)$.

${ }^{c}$ Undefined $(n=220)$.

There was a positive visual correlation between the WHOQOL scores evaluated (WHOQOL-1 and WHOQOL-2) and the QoL/Satisfaction groups with the OQoL score (Figure 1). Possible definition of a cut-off point was observed by differentiating the G5 and G6 groups when evaluating the QoL satisfaction groups.

Analysis of the ROC curve indicated a critical value of 60 as the best cut-off point for evaluating perceived quality of life and satisfaction with health (Figure 2). The area beneath the curve was 0.758 , with a sensitivity of $76.8 \%$ and $63.8 \%$ specificity for the OQoL cut-off

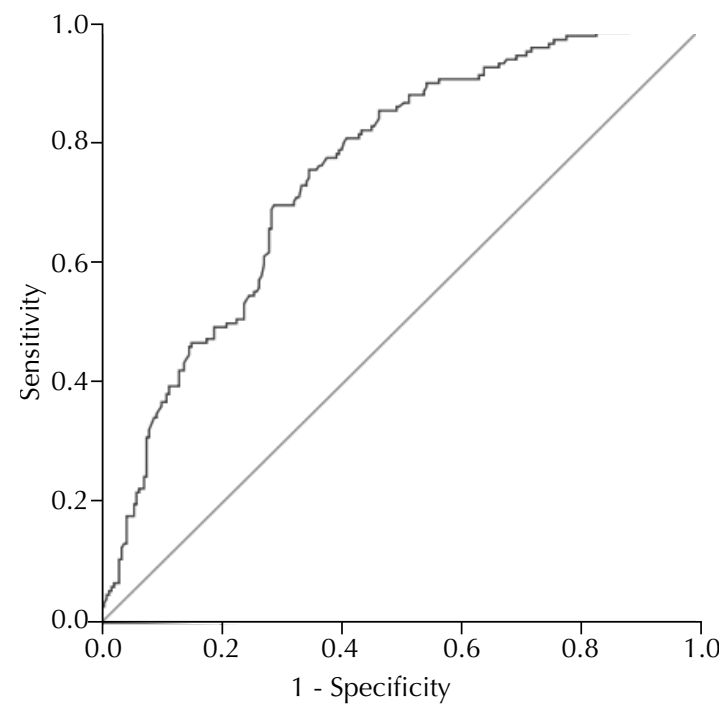

Figure 2. ROC curve showing sensitivity and specificity of cut-off points to predict good quality of life/satisfied (G5) or poor quality of life/dissatisfied (G6), considering the G5 and G6 groups in the sample studied. Northwest Health District, Belo Horizonte, MG, 2010 to 2011. point $\geq 60$ in older adults in group G5; and $95.0 \%$ sensitivity and $54.4 \%$ specificity for the OQoL cut-off point $\geq 60$ in older adults in group G6.

Tables 2 and 3 show the diagnostic capacity of the OQoL score in correctly classifying older adults with good QoL/satisfied in group G5, using a cut-off point of $\geq 60$, and classifying them correctly with poor QoL/ dissatisfied into group G6, using the $<60$ cut-off point.

\section{DISCUSSION}

The sample was predominantly feminine, with a low level of schooling and a high rate of chronic co-morbidities, as seen in other Brazilian studies. ${ }^{5,7}$ The test with an $\mathrm{OQoL} \geq 60$ cut-off point was moderately sensitive for recognizing individuals with good/satisfactory QoL in Brazilian older adults. On the other hand, the sensitivity of the test with the OQoL $<60$ cut-off point was optimum, as was the negative predictive value for screening older adults whose QoL was poor/unsatisfactory. The result of the positive likelihood ratio for the first situation showed that the effect on post-test probability for positive results is minimal, whereas, in the second situation, the negative likelihood ratio showed that post-test probability for negative results is greatly affected and serves as a good marker for screening individuals with poor/unsatisfactory $\mathrm{QoL}$ when the $\mathrm{OQoL}$ is below 60 , with $95.0 \%$ sensitivity and negative predictive value of $99.5 \%$.

Although the first two questions in the WHOQOL-bref are included in the overall score, they serve to stratify the older population regarding their perceptions of quality of life and health. The population was classified by mixing better and worse perceptions of these two issues simultaneously, based on the extremes. Individuals whose perceptions were intermediate (e.g., 
Table 2. Capacity to diagnose overall quality of life, according to the cut-off points defined to screen quality of life in quality of life/satisfaction groups. Northwest Health District, Belo Horizonte, MG, 2010 to 2011.

\begin{tabular}{|c|c|c|c|c|c|c|c|}
\hline \multirow{2}{*}{ Variable } & & \multicolumn{2}{|c|}{ G5 } & \multirow{2}{*}{ Total } & \multicolumn{2}{|c|}{ G6 } & \multirow{2}{*}{ Total } \\
\hline & & Yes & No & & Yes & No & \\
\hline \multirow{2}{*}{ OQoL $\geq 60$} & Yes & 116 & 87 & 203 & & & \\
\hline & No & 35 & 153 & 188 & & & \\
\hline Total & & 151 & 240 & 391 & & & \\
\hline \multirow{2}{*}{ OQoL $<60$} & Yes & & & & 19 & 169 & 188 \\
\hline & No & & & & 1 & 202 & 203 \\
\hline Total & & & & & 20 & 371 & 391 \\
\hline
\end{tabular}

OQoL: Overall Quality of Life; G6: Poor quality of life/dissatisfied; G5: Good quality of life/satisfied

good QoL and dissatisfied with health, or vice-versa) were excluded. Despite the weighting of these two questions being influential, the weights tend to cancel each other out (better versus worse), with the other four domains that evaluate different issues predominating. Thus, it was not used as a gold standard, but rather as strata of extremes of perception (better versus worse). This does not invalidate the aim of the study, which relativized the strata by setting a cut-off point. This is not simply a number but rather a reference to make comparisons between different populations concerning their perceived QoL and health.

Before applying the results of this study, it is necessary to examine them critically, in the light of scientific evidence provided by other studies, preferably longitudinal and population-based. A greater number of individuals in the G5 group could be included. This would enable us to evaluate whether this critical value is capable of discriminating populations with better or worse quality of life and health, as well as evaluating the possibility of making comparisons between different populations.

The lack of national and international studies for cut-off points specific to evaluating quality of life makes it impossible for comparisons with other research to be made. In addition, the sample of the clientele is non-probablistic. Another limitation concerns the lower number of participants in the poor/ dissatisfied QoL group.

Questions were raised and expectations considered regarding the adoption of a cut-off point for the WHOQOL-bref based on creating groups at the two extremes simultaneously. Future studies should analyze different cut-off points for discriminating better or worse quality of life in the elderly and in other age groups. Thus, the existence of any alterations in critical values according to perceived quality of life and general state of health could be identified and compared.

The second stage of this research is in progress and aims to validate this cut-off point using a longitudinal study with an older adult population base.

\section{ACKNOWLEDGEMENTS}

To the members of the Núcleo de Estudos e Pesquisas em Cuidado e Desenvolvimento Humano, da Escola de Enfermagem da Universidade Federal de Minas Gerais: Ana Luiza de Aquino and Gislene Pace de Souza Santos who participated in the data collection and Elenice Dias Ribeiro de Paula Lima and Maria Teresinha de Oliveira Fernandes who participated in conceiving the research and the data collection and analysis stages.

Table 3. Indicators of capacity to diagnose overall quality of life according to the cut-off points defined to screen quality of life in quality of life/satisfaction groups. Northwest Health District, Belo Horizonte, MG, 2010 to 2011.

\begin{tabular}{lcc}
\hline Indicadores de capacidade diagnóstica & G5 (\%) (cut-off point $\geq 60)$ & G6 (\%) (cut-off point < 60) \\
Sensitivity & 76.8 & 95.0 \\
Specificity & 63.7 & 54.4 \\
Positive predictive value & 57.1 & 10.1 \\
Negative predictive value & 81.4 & 99.5 \\
Positive likelihood ratio & 2.1 & 2.1 \\
Negative likelihood ratio & 0.4 & 0.1 \\
\hline
\end{tabular}

G6: Poor quality of life/dissatisfied; G5: Good quality of life/satisfied 


\section{REFERENCES}

1. Alexandre TS, Cordeiro RC, Ramos LR. Factors associated to quality of life in active elderly. Rev Saude Publica. 2009;43(4):613-21. DOI:10.1590/S0034-89102009005000030

2. Anand D, Puri S, Mathew M. Assessment of quality of life of HIV-positive people receiving ART: an Indian perspective. Indian I Community Med. 2012;37(3):165-9. DOI:10.4103/0970-0218.99918

3. Braga SFM, Peixoto SV, Gomes IC, Acúrcio FA, Andrade EIG, Cherchiglia ML. Factors associated with health-related quality of life in elderly patients on hemodialysis. Rev Saude Publica. 2011;45(6):1127-36. DOI:10.1590/S0034-89102011000600015

4. Fleck MPA, Leal OF, Louzada S, Xavier M Chachamovich E, Vieira G, et al. Desenvolvimento da versão em português do instrumento de avaliação de qualidade de vida da OMS (WHOQOL-100). Rev Bras Psiquiatr. 1999;21(1):19-28. DOI:10.1590/S1516-44461999000100006

5. Fleck MPA. O instrumento de avaliação de qualidade de vida da Organização Mundial da Saúde (WHOQOL-100): características e perspectivas. Cienc Saude Coletiva. 2000;5(1):33-8. DOI:10.1590/S1413-81232000000100004

6. Fleck MPA, Louzada S, Xavier M, Chachamovich E, Vieira G, Santos L, et al. Aplicação da versão em português do instrumento abreviado de avaliação da qualidade de vida "WHOQOL-bref". Rev Saude Publica. 2000;34(2):178-83. DOI:10.1590/S0034-89102000000200012

7. Gampel D, Karsch UM, Ferreira LP. Percepção de voz e qualidade de vida em idosos professores e não professores. Cienc Saude Coletiva. 2010;15(6):2907-16. DOI:10.1590/S1413-81232010000600028

8. Joia LC, Ruiz T, Donalisio MR. Condições associadas ao grau de satisfação com a vida entre a população de idosos. Rev Saude Publica. 2007;41(1):131-8. DOI:10.1590/S0034-89102007000100018

9. Kim DH, Li K, Seo SJ, Jo SJ, Yim HW, Kim CM, et al. Quality of life and disease severity are correlated in patients with atopic dermatitis. J Korean Med Sci. 2012;27(11):1327-32. DOI:10.3346/jkms.2012.27.11.1327
10. Kimura M, Silva JV. Ferrans and Powers quality of life index. Rev EsC Enferm USP. 2009;43(№ Espec):1098-104. DOI:10.1590/S0080-62342009000500014

11. Lima MG, Barros MBA, César CLG, Goldbaum M, Carandina L, Alves MCGP. Health-related behavior and quality of life among the elderly: a populationbased study. Rev Saude Publica. 2011;45(3):485-93. DOI:10.1590/S0034-89102011000300006

12. Lwanga SK, Lemeshow S. Sample size determination in health studies: a practical manual. Geneva: WHO; 1991.

13. Meirelles BHS, Arruda C, Simon E, Vieira FMA, Cortezi MDV, Natividade MSL. Condições associadas à qualidade de vida dos idosos com doença crônica. Cogitare Enferm. 2010;15(3):433-40.

14. Mungas D. In-office mental status testing: a practical guide. Geriatrics. 1991;46(7):54-8, 63, 66.

15. Paskulin LMG, Molzahn A. Quality of life of older adults in Canada and Brazil. West I Nurs Res. 2007;29(1):10-26. DOI:10.1177/0193945906292550

16. Pereira RJ, Cotta RMM, Franceschini SCC, Ribeiro RCL, Sampaio RF, Priore SE, et al. Contribution of the physical, social, psychological and environmental domains to overall quality of life of the elderly. Rev Psiquiatr Rio Gd Sul. 2006;28(1):27-38. DOI:10.1590/S0101-81082006000100005

17. Pereira RJ, Cotta RMM, Franceschini SCC, Ribeiro $\mathrm{RCL}$, Sampaio RF, Priore SE, et al. Influência de fatores sociossanitários na qualidade de vida dos idosos de um município do Sudeste do Brasil. Cienc Saude Coletiva. 2011;16(6):2907-17. DOI:10.1590/S1413-81232011000600028

18. Ramos LR. Fatores determinantes do envelhecimento saudável em idosos residentes em centro urbano: Projeto Epidoso, São Paulo. Cad Saude Publica. 2003;19(3):793-8. DOI:10.1590/S0102-311X2003000300011

19. World Health Organization Quality of Life Group. The World Health Organization Quality of Life assessment (WHOQOL): position paper from the World Health Organization. Soc Sci Med. 1995;41(10):1403-9.

Article based on the master's dissertation of Silva PAB, entitled: "Fatores associados à qualidade de vida de idosos adscritos no Distrito Sanitário Noroeste de Belo Horizonte, Minas Gerais", presented to the Escola de Enfermagem da Universidade Federal de Minas Gerais, in 2012.

This study was supported by the Fundação de Amparo à Pesquisa do Estado de Minas Gerais (Process APQ-00570-9). The study was presented at the I Workshop on Healthy Aging, Belo Horizonte, MG, 2012.

The authors declare that there is no conflict of interest. 